\title{
PENINGKATAN PEMBELAJARAN PPKN MATERI PERSIAPAN KEMERDEKAANINDONESIA MELALUI PENDEKATAN CONTEXTUAL TEACHING AND LEARNING (CTL) PADA SISWA KELAS VI SD NEGERI MUKA BLANG
}

\author{
Mariana \\ SD Negeri Muka Blang \\ Marianaana10@gmail.com
}

\begin{abstract}
Abstrak
Latar belakang permasalahan pembelajaran PKN pada siswa Kelas VI SD Negeri Muka Blang. Guru belum mengaitkan pembelajaran dengan dunia nyata siswa. Hal ini ditunjukkan dari 19 siswa, 14 siswa (74\%) mendapat nilai di bawah KKM yaitu $<70$ dan 5 siswa (26\%) di atas KKM. Untuk memperbaiki hal tersebut peneliti menerapkan pendekatan CTL pada pembelajaran PKN. Rumusan masalah penelitian ini bagaimanakah cara meningkatkan kualitas pembelajaran PKN pada siswa Kelas VI SD Negeri Muka Blang?. Tujuan penelitian ini untuk mendeskripsikan kualitas pembelajaran PKN pada siswa Kelas VI SD Negeri Muka Blang. Analisis data menggunakan analisis deskriptif kuantitatif dan analisis deskriptif kualitatif. Hasil penelitian hasil belajar siswa pada siklus I ketuntasan siswa adalah 70,53 atau 53\%. Siklus II ketuntasan siswa meningkat menjadi 79,74 atau 95\%. Kesimpulan, melalui pendekatan CTL dapat meningkatkan hasil belajar siswa Kelas VI SD Negeri Muka Blang pada pembelajaran PKN. Penerapan model pembelajaran ini dapat dijadikan sebagai solusi untuk meningkatkan kualitas pembelajaran untuk mata pelajaran yang lainnya karena CTL membantu siswa mengaitkan pengetahuan dengan dunia nyata.
\end{abstract}

Kata Kunci: Pembelajaran PPkN, Pendekatan Contextual Teaching And Learning (CTL)

\begin{abstract}
The background of PKN learning problems in Class VI students at Blang State Elementary School. The teacher has not linked learning with the real world of students. This is indicated by 19 students, 14 students (74\%) scored below KKM which is $<70$ and 5 students (26\%) above KKM. To correct this, researchers applied the CTL approach to PKN learning. The formulation of this research problem is how to improve the quality of PKN learning in Class VI students of SD Negeri Blang ?. The purpose of this study was to describe the quality of PKN learning in Class VI students at Blang State Elementary School. Data analysis used quantitative descriptive analysis and qualitative descriptive analysis. The research results of student learning outcomes in the first cycle of student completeness were 70.53 or $53 \%$. The second cycle of student completeness increased to 79.74 or $95 \%$. Conclusion, through the CTL approach can improve the learning outcomes of Class VI students of SD Negeri Blang in PKN learning. The application of this learning model can be used as a solution to improve the quality of learning for other subjects because CTL helps students associate knowledge with the real world.
\end{abstract}

Keywords: PPkN Learning, Contextual Teaching And Learning (CTL) Approach

\section{LATAR BELAKANG}

Pelaksanaan pembelajaran Pendidikan

Kewarganegaraan (PKn) hingga saat ini masih menemui kendala. Pendidikan

$\begin{array}{lcr}\text { Kewarganegaraan } & \text { (civic } & \text { education) } \\ \text { merupakan salah satu kajian yang } \\ \text { mengemban misi } & \text { nasional untuk } \\ \text { mencerdaskan kehidupan bangsa Indonesia }\end{array}$


melalui koridor value-based education. Tujuannya yaitu untuk mengembangkan potensi individu agar menjadi warga Negara Indonesia yang berakhlak mulia, cerdas, partisipatif, dan bertanggung jawab, serta dirancang secara progmatik sebagai subjek pembelajaran yang menekankan pada isi yang mengusung nilai-nilai dan pengalaman belajar.

Dalam realita yang terjadi, guru-guru PKn cenderung menerapkan pembelajaran konvensional yaitu dengan metode ceramah. Tujuan pembelajaran nya yaitu cenderung mengacu pada pencapaian verbal. Kegiatan belajar siswa berorientasi pada penguasaan materi buku teks. Tujuan akhirnya yaitu agar siswa mendapat nilai yang tinggi pada pelaksanaan tes sumatif maupun ujian sekolah. (Budimansyah, 2010:118). Pada saat Pembelajaran PKn banyak Siswa Kelas VI SD Negeri Muka Blang yang jenuh, kurang semangatdalam kegiatan proses belajar mengajar sehingga haswil belajar tidak maksimal.

Berdasarkan pokok masalah yang telah penulis uraikandi atas, maka penulis ingin melakukan penelitian yang berhubungan dengan potensi peserta didik dari ketiga ranah yang ada yaitu kognitif, afektif, dan psikomotorik. Jadi penulis menetapkan judul "PeningkatanHasil Belajar Pembelajaran PKn Materi Persiapan Kemerdekaan Indonesia melalui Pendekatan Contextual Teaching and Learning (CTL) pada Siswa Kelas VI SD Negeri Muka Blang".

\section{KERANGKA TEORITIS}

Pengertian Belajar

Belajar merupakan sebuah proses perubahan di dalam kepribadian manusia dikarenakan pengalaman yang dimiliki. Perubahan tersebut tampak dalam bentuk peningkatan kualitas dan kuantitas tingkah laku seperti peningkatan kecakapan, pengetahuan, sikap, kebiasaan, pemahaman, keterampilan, daya pikir, serta kemampuankemampuan yang lain. Pendapat tersebut didukung Slavin (dalam Rifa'i, 2009:82),
Senada, Hilgard dan Bower (dalam Baharudin 2010:13), Belajar merupakan proses memperoleh pengetahuan melalui pengalaman, mengingat, menguasai dan mendapatkan informasi atau menemukan. sesuai pendapat Winataputra (2007:14), belajar diartikan penggunaan pengalaman dengan mengetahui serta mendapat pengetahuan berupa kemampuan, keterampilan, dan sikap untuk menjadi panduan di masa depan.

Berdasarkan pendapat diatas maka dapat penulis simpulkan bahwa belajar adalah perubahan relatif permanen dalam perilaku atau potensi perilaku sebagai hasil dari pengalaman atau latihan, dari tidak baik menjadi baik dan dari tidak tau menjadi tau. Pembelajaran

Briggs dalam Rifa'i dan Anni (2009:191)menyatakan bahwa pembelajaran adalah seperangkat peristiwa (events) yang mempengaruhi peserta didik sedemikian rupa sehingga peserta didik itu memperoleh kemudahan. Unsur utama dari pembelajaran adalah pengalaman anak sebagai seperangkat event sehingga terjadi proses belajar. Dengan demikian pendidikan, pengajaran, dan pembelajaran, mempunyai hubungan konseptual yang tidak berbeda.

Sedangkan Winataputra (2007:1.34) Pembelajaran berorientasi pada proses belajar isyarat, dimulai dengan adanya tanda atau isyarat mempunyai pengaruh pada proses perubahan perilaku. Proses yang baik memungkinkan terjadinya relasi antara stimulus dan respon dengan baik. Hubungan stimulus respon harus dikuasai peserta didik untuk memungkinkan pencapaian keberhasilan pada belajar rangkaian dan asosiasiverbal. Asosiasi verbal menggunakan konsep, benda, prinsip, situasi, dan informasi terorganisir secara bersistem di ingatan nya. Berdasarkan beberapa pengertianahli diatas dapat penulis simpulkan bahwa pembelajaran adalah setiap kegiatan peningkatan kualitas, serta 
pemfasilitasan belajar bagi peserta didik yang merupakan aktivitas paling utama.

Kualitas Pembelajaran

Kualitas dapat dimaknai dengan istilah mutu atau keefektifan. Secara definitif efektifitas dapat dinyatakan sebagai tingkat keberhasilan dalam mencapai tujuan atau sasarannya. Efektifitas tidak hanya dilihat dari sisi produktivitas, tetapi juga dapat dilihat dari sisipersepsi atu sikap orangnya.

Sedangkan secara operasional diartikan intensitas keterkaitan sistemik dan sinergis keterampilan guru, aktivitas peserta didik, kurikulum dan bahan ajar, media, fasilitas, sistem pembelajaran dalam menghasilkan proses serta hasil belajar optimal sesuai tuntutan kurikuler (Depdiknas, 2004:7). Perilaku pembelajaran guru dapat dilihat dari kinerjanya sebagai berikut: (a) membangun sikap positif siswa terhadap belajar dan profesi; (b) menguasai disiplin ilmu; (c) guru perlu memahami keunikan siswa; (d) menguasai pengelolaan pembelajaran yang mendidik, dan; (e) Mengembangkan kepribadian dan keprofesionalan.

Indikator kualitas dapat dilihat dari perilaku pembelajaran dosen atau pendidik guru, perilaku dan dampak belajar siswa, iklim, materi,dan media belajar. Sistem pembelajaran di sekolah menunjukkan kualitas jika: (a) sekolah dapat menonjolkan ciri khas keunggulannya; (b) memiliki perencanaan yang matang dalam bentuk rencana strategis dan rencana operasional sekolah; (c) ada semangat perubahan yang dicanangkan dalam visi dan misi sekolah; (d) pengendalian dan penjaminan mutu.

Dalam penelitian ini, untuk mengetahui kualitas pembelajaran peneliti membatasi 3 indikator kualitas pembelajaraan. Ketiganya adalah keterampilan guru, aktivitas siswa, hasil belajar dijadikan variabel dalam penelitian. Dikarenakan ketiga indikator tersebut sesuai dengan konsep pembelajaran malalui pendekatan Contextual Teaching and
Learning (CTL) yang sesuai dengan dunia nyata mengaitkan antara kemampuan guru dalam mengelola kegiatan belajar mengajar dengan memanfaatkan lingkungan sebagai sumber belajar menjadikan aktifnya siswa berakibat meningkatnya hasil belajar.

\section{Keterampilan guru}

Pembelajaran merupakan suatu proses kompleks melibatkan berbagai aspek yang saling berkaitan. oleh karena itu, untuk mewujudkan pembelajaran yang efektif diperlukan keterampilan.Keterampilan mengajar atau membelajarkan merupakan kompetensi pedagogik yang cukup kompleks karena merupakan integrasi dari berbagai kompetensi guru secara menyeluruh dalam proses belajar mengajar.

Keterampilan dasar untuk guru dibutuhkan supaya dapat melaksanakan perannya dalam pengelolaan pembelajaran dapat berjalan efektif efisien. Keterampilan yang dimiliki guru adalah syarat mutlak mengimplementasikan berbagai strategi belajar mengajar (Sanjaya, 2012:33).

Rusman, (2011:80) menjelaskan 9 keterampilan dasar yang harus dimiliki seorang pendidik:

a. Keterampilan membuka pelajaran

Keterampilan membuka pelajaran merupakan kegiatan guru untuk menciptakan siap mental dan menimbulkan perhatian siswa agar terpusat pada yang dipelajari. Membuka pelajaran dilakukan dengan set condition, yakni usaha atau kegiatan guru dalam pembelajaran untuk menciptakan prakondisi bagi siswa agar mental maupun perhatiannya terpusat pada bahan atau materi yang akan dipelajarinya sehingga memberikan efek positif terhadap kegiatan pembelajaran.

b. Keterampilan bertanya

Bertanya adalah ucapan secara verbal meminta repon dari seseorang yang ditujukan. Keterampilan bertanya merupakan keterampilan yang digunakan guru untuk mendapatkan jawaban dari siswa atas pertanyaan yang diberikan. Dengan bertanya akan membantu siswa dalam belajar dengan temannya, membantu siswa 
lebih sempurna dalam menerima informasi, dan dapat mengembangkan keterampilan kognitif tingkat tinggi.

\section{c. Keterampilan memberi penguatan}

Penguatan adalah respon positif dilakukan guru atas perilaku positif yang dicapai siswa dalam proses belajar, dengan tujuan untuk mempertahankan dan meningkatkan perilaku tersebut.

d. Keterampilan mengadakan variasi

Keterampilan menggunakan variasi merupakan salah satu keterampilan mengajar yang harus dikuasai oleh guru. Keterampilan menggunakan variasi diartikan sebagi kegiatan guru dalam rangka mengubah situasi dengan mengubah gaya mengajar, menggunakan media pembelajaran atau mengubah pola interaksi dengan maksud menciptakan suasana pembelajaran yang lebih menyenangkan, sehingga siswa siswa senantiasa tekun, antusias, serta berperan aktif dalam kegiatan pembelajaran.

e. Keterampilan menjelaskan

Menjelaskan berarti memberikan informasi secara lisan yang diorganisasi secra sistematis untuk menunjukkan adanya hubungan sebab akibat, antara generalisasi dengan konsep, antara fakta dengan konsep, ataupun sebaliknya. Keberhasilan guru dalam menjelaskan ditentukn oleh tingkat pemahaman yang ditentukan oleh siswa yang diajarnya.

f. Keterampilan membimbing diskusi

kelompok kecil

Diskusi kelompok kecil adalah suatu proses yang teratur yang melibatkan sekelompok individu dalam suatu interaksi tatap muka secara kooperatif dengan tujuan membagi informasi, membuat keputusan dan memecahkan masalah. Diskusi kelompok kecil sangat bermanfaat dalam memberikan pengalaman pendidikan bagi siswa yang terlibat aktif didalamnya.

g. Keterampilan mengelola kelas

Pengelolaan kelas adalah keterampilan guru dalam menciptakan dan memelihara kondisi belajar yang optimal dan mengembalikannya bila terjadi gangguan dalam kegiatan pembelajaran. Pengelolaan kelas merupakan masalah yang kompleks, guru menggunakannya untuk menciptakan dan mempertahankan kondisi kelas untuk mencapai tujuan pengajaran secara efisisen dan memungkinkan siswa dapat belajar secara maksimal. Pengelolaan kelas yang efektif merupakan prasyarat mutlak dalam terjadinya kegiatan pembelajaran yang efektif.

h. Keterampilan pembelajaran

perseorangan

Pengajaran perorangan diartikan sebagai suatu proses di mana setiap siswa dibantu dalam mengembangkan kemajuan dalam mencapai tujuan berdasarkan kemampuan, pendekatan, dan bahan pelajaran. Keterampilan ini akan meningkatkan pemahaman guru dan siswa yang terlibat, dan pemahaman dalam mengorganisasi suatu kegiatan pembelajaran. Pengajaran perorangan dapat dilaksanakan bila setiap siswa memegang peranan penting dalam pemilihan tujuan, materi, prosedur, dan waktu yang diperlukan.

Keterampilan menutup pelajaran Keterampilan menutup pelajaran adalah kegiatan guru untuk mengakhiri kegiatan inti pelajaran. Ketika menutup pelajaran, kegiatan yang dilakukan guru adalah mengakhiri kegiatan pembelajaran. Usaha menutup pelajaran dimaksudkan untuk memberi gambaran menyeluruh tentang apa yang telah dipelajari olehsiswa, mengetahui tingkat pencapaian siswa, dan tingkat keberhasilan guru dalam pelaksanaan kegiatan pembelajaran.

Dari uraian di atas tentang keterampilan guru, disimpulkan dalam pembelajaran terdapat kunci mencapai kesuksesan sesuai tujuannya yakni guru. Guru harus mempunyai keterampilan mengajar, dikarenakan tanpa adanya hal ini menjadikan pembelajaran tidak akan berlangsung dengan baik serta tidak tercapai tujuan pembelajaran seperti yang telah dirumuskan

\section{Hakikat Pendidikan Kewarganegaraan}


Padahakikatnyapendidikan

kewarganegaraan merupakan sebuah metode pendidikan yang bersumber pada nilai nilai Pancasila sebagai kepribadian bangsa demi meningkatkan serta melestarikan keluhuran moral dan perilaku masyarakat yang bersumber pada budaya bangsa yang ada sejak dahulu kala.

Dengan hal tersebut diharapkan dapat mencerminkan jati diri yang terwujud dalam berbagai tingkah laku di dalam kehidupan keseharian masyarakat. Hakikat pendidikan kewarganegaraan sebagai sebuah mata pelajaran ialah memiliki sebuah tujuan penting dalam membentuk jati diri individu yang hidup dalam kehidupan masyarakat yang majemuk. Baik dalam kemajemukan suku, agama, ras dan budaya serta bahasa demi membangun karakter bangsa sebagai bangsa yang cerdas, cakap dan memiliki karakter yang berlandaskan UUD 1945 dan Pancasila sebagai filsafat bangsa.

Kurikulum Tingkat Satuan Pendidikan (Depdiknas:2006) menyebutkan mata pelajaran pendidikan kewarganegaraan merupakan mata pelajaran yang memfokuskan pada pembentukan warga negara yang memahami dan mampu melaksanakan hak-hak dan kewajibannya untuk menjadi warga negara Indonesia yang cerdas, terampil, dan berkarakter yang diamanatkan oleh Pancasila dan UUD 1945.

PendidikanKewarganegaraan

merupakan mata pelajaran sosial yang bertujuan untuk membentuk atau membina warga negara yang baik, yaitu warga negara yang tahu, mau dan mampu berbuat baik. (Ruminiati, 2007:1.25). Somantri dalam Ian (2010) menyebutkan istilah kewargaannegara merupakan terjemahan dari "civics" yang merupakan mata pelajaran sosial yang bertujuan membina dan mengembangkan anak didik agar menjadi warga negara yang baik (good citizen). Warga negara yang baik adalah warga negara yang tahu, mau, dan mampu berbuat baik atau secara umum yang mengetahui, menyadari, dan melaksanakan hak dan kewajibannya sebagai warga negara.
PPKn dinilai sebagai mata pelajaran yang mengusung misi pendidikan nilai dan moral dengan alasan sebagai berikut (Ian: 2010):

a. Materi PPKn adalah konsep-konsep nilai Pancasila dan UUD 1945 beserta dinamika peerwujudan dalam kehidupan masyarakat negara Indonesia.

b. Sasaran akhir belajar PPKn adalah perwujudan nilai-nilai tersebut dalam prilaku nyata dalam kehidupan seharihari.

Dapat penulis simpulkan bahwa hakekatPendidikan Kewarganegaraan adalah upaya yang dilakukan secara sadar dan terencana untuk mencerdaskan kehidupan bangsa bagi warga negara dengan mengedepankan jati diri yang baik dan menumbuh kembangkan sikap demi kelangsungan kehidupan dan kejayaan bangsa Indonesia

\section{Persiapan Kemerdekaan Indonesia}

Pada 1944 Jepang semakin terdesak oleh Sekutu. Akhirnya, pada 7 September1944 Perdana Menteri Jepang Jenderal Kois memberi janji kemerdekaan kepada bangsa Indonesia. Pada 1 Maret 1945 dibentuk Badan Penyelidik Usaha Persiapan Kemerdekaan Indonesia (BPUPKI) atau Dokuritsu Junbi Cosakai Badan ini kemudian dibubarkan pada 7 Agustus 1945. Sebagai gantinya dibentuk Panitia Persiapan Kemerdekaan Indonesia (PPKI) atau Dokuritsu Junbi Inkai. Selanjutnya Jepang memanggil tiga tokoh PPKI, yaitu Ir. Soekarno, Drs.Moh. Hatta, dan dr. Radjiman Wedyodiningrat ke Vietnam pada 12 Agustus 1945.Pemerintah Jepang memutuskan untuk memberi kemerdekaan kepada Indonesia melalui PPKI.

\section{Pendekatan Contextual Teaching And Learning (CTL)}

Rifa'i, (2009:237) menjelaskan bahwa pembelajaran kontekstual merupakan proses pendidikan bertujuan menolong peserta didik pahami dan melihat makna dalam materi akademik dipelajari malalui cara menghubungkan subjek-subjek akademik 
dengan konteks dunia nyata keseharian hidup mereka, yaitu konteks keadaan pribadi, sosial, budaya.

Nurhadi (2003:11) CTL adalah konsep pembelajaran dengan menghadirkan dunia nyata dalam kelas dan mendorong siswa mengaitkan pengetahuan yang dimiliki dengan kehidupan nyata sehari-hari. Senada dengan hal tersebut, Elaine B. Jhonson (Riwayat, 2008) menjelaskan pembelajaran yang merangsang otak untuk menyusun pola-pola mewujudkan makna sesuai dengan konteks kehidupan nyata. Kontekstual adalah sistem pembelajaran yang cocok dengan otak, karena menghasilkan makna yang menghubungkan muatan akademis dengan konteks dari kehidupan sehari-hari (Rusman, 2011:187).

SedangkanSugandi

(2008:30),

menyebutkan bahwa pendekatan kontekstual merupakanpembelajaran untuk meningkatkan prestasi belajar siswa melalui pemahaman materi pelajaran yang mengaitkan antar materi dengan kehidupan nyata anak didik sehari-hari. Esensi atau isi inti pengajaran terdapat pada pengaitan materi ajar anak didik dan konteks kehidupan nyata.

Sugandi, (2008:125)menyatakan untuk mencapai tujuan pembelajaran kontekstual diharapkan

1. Guru yang berwawasan.

2. Materi dalam pembelajaran.

3. Strategi metode dan teknik belajar meng jar.

4. Media pendidikan.

5. Fasilitas

6. Proses belajar dan mengajar.

7. Kancah pembelajaran

8. Penilaian.

9. Suasana.

Dapat disimpulkan bahwa pendekatan kontekstual adalah konsep belajar yang membantu peserta didik mengaitkan materi diajarkan dengan dunia nyata serta mendorong membuat hubungan antara pengetahuan dimiliki, penerapan kehidupan sehari-hari.

\section{METODOLOGI PENELITIAN Waktu dan Lokasi Penelitian}

Penelitian ini dilaksanakan dari tanggal 12 Juli sd 18 November 2016 di SD
Negeri Muka Blang Jalan Panteraja Muka Blang Kecamatan Panteraja Kabupaten Pidie Jaya.

\section{Pendekatan Penelitian}

Pada proses penelitian hendaknya dapat menentukan suatu metode penelitian yang akan digunakan,hal ini berdasarkan pada suatu pemahaman bahwa metode penelitian dapat dijadikan suatu cara atau langkah untuk memperoleh suatu data, meganalisis data, sehingga pada akhirnya akan mendapatkan hasil dari sasaran serta tujuan penelitian yang dilakukan. Dalam mencapai tujuan yang diinginkan pada penelitian yang dilakukan maka penting sekali bagi peneliti untuk memilih metode penelitian yang tepat sebagaimetode penelitian yang akan dicapai.

Penggunaan metode penelitian sangat tergantung kepada permasalahan yang akan dibahas, hal ini dapat diartikan bahwa penggunaan suatu metode penelitian dapat dilihat dari segi efektifitas, efesiensi serta relevansinya metode penelitian tersebut dengan permasalahan pada sebuah penelitian yang dilakukan. Metode penelitian dikatakan efektif apabila selama pelaksanaan penelitian dapat terlihat adanya suatu perubahan positif kearah tujuan yang diharapkan, sedangkan apabila dalam pelaksanaan penelitian penggunaan waktu,fasilitas,biaya,dan tenaga dapat terlaksana dengan sehemat mungkin akan tetapi tujuan penelitian tetap tercapai maka metode tersebut dikatakan efisien dalam sebuah penelitian. Selanjutnya penelitian dapat dikatakan relevan apabila penelitian tersebut berjalan dengan lancer serta dapat menghasilkan hasil sesuai dengan tujuan penelitian serta adanya kesesuaian antara waktu penggunaan hasil pengolahan dengan tujuan yang akan dicapai pada suatu penelitian tidak terjadi penyimpangan.

Pendekatan dalam penelitian ini menggunakan pendekatan penelitian kualitatif karena penelitian ini bersifat deskriptif dan naturalistik. Penelitian ini bersifat deskriptif karena hanya mendeskripsikan tentang hasilpeningkatan pembelajaran Pkn Materi Persiapan Kemerdekaan Indonesia Melalui Pendekatan Contextual Teaching And Learning (CTL) 
Pada siswa kelas VI SD Negeri Muka Blang. Pendekatan kualitatif bersifat naturalistik karena penelitian ini memang terjadi secara alamiah, apa adanya, dalam situasi normal yang tidak memanipulasi keadaan dan kondisinya. Kedua sifat penelitian kualitatif tersebut menuntut keterlibatan peneliti secara langsung (partisipasi aktif) baik pada awal pembelajaran maupun yang terjadi setelah diterapkannya tindakan di lapangan.

\section{Jenis Penelitian}

Jenis penelitian ini adalah jenis Penelitian Tindakan Sekolah (School Action Research) karena penelitian dilakukan oleh Kepala Sekolah di sekolahnya sendiri dengan jalan merancang, melaksanakan, dan merefleksikan tindakan secara kolaboratif dan partisipatif dengan tujuan untuk memperbaiki kinerja kepalasekolah sehinggahasil belajar siswa dapat meningkat. Penelitian Tindakan sekolah yang digunakan dalam penelitian ini adalah Model Kurt Lewin yang terdiri dari empat komponen, yaitu: a) perencanaan (planning); b) tindakan (acting; c) pengamatan (observing; dan d) refleksi (refecting)

\section{Rancangan Penelitian}

Rancangan model penelitian yang dipakai dalam penelitian ini adalah menggunakan Penelitian Tindakan Kelas model spiral atau siklus menurut Arikunto (2009:16), bertujuan apabila dalam pelaksanaan tindakan ditemukan adanya kekurangan, maka dapat dilakukan perbaikan yang dilanjutkan pada siklus berikutnya sampai target diinginkan tercapai. Dalam setiap siklus terdiri dari empat tahapan yaitu perencanaan, pelaksanaan tindakan, observasi, dan refleksiRancangan Penelitian sebagai berikut:

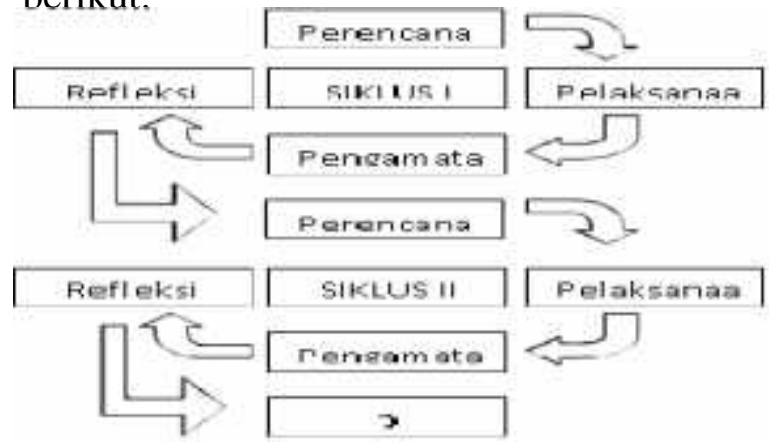

Menurut Arikunto, (2009:17) langkahlangkah penelitian dilaksanakan dalam tahapan.

\section{Perencanaan}

Didalam tahap perencanaan, peneliti menentukan fokus peristiwa yang perlu mendapatkan perhatian khusus untuk diamati, kemudian dilanjutkan membuat sebuah instrumen pengamatan untuk membantu peneliti mengambil data dalam merekam fakta yang terjadi selama tindakan

\section{Pelaksanaan Tindakan}

Pelaksanaan tindakan yakni implementasi atau penerapan isi rancangan di dalam kancah, yaitu mengenakan tindakan di kelas. Dalam tahap pelaksanaan tindakan guru melaksanakan pembelajaran dengan menggunakan pendekatan Contextual Teaching and Learning (CTL) sesuai materi akan diajarkan. Kolaborator berperan untuk melakukan pengamatan dalam pelaksanaan tindakan atau kegiatan pembelajaran

\section{Observasi}

Observasi atau pengamatan yaitu pelaksanaan pengamatan oleh pengamat yang dilakukan secara teliti dan dan melakukan pencatatan secara sistematis Pelaksanaan observasi atau pengamatan bersamaan dengan pelaksanaan tindakan atau kegiatan pembelajaran. Dalam tahap ini kolaborator melakukan pengamatan dan mendokumentasikan keterampilan guru, aktivitas siswa, hasil belajar. Pengamatan dilakukan dengan menggunakan pedoman observasi.

\section{Refleksi}

Refleksi adalah perenungan kembali atas apa yang telah dilakukan untuk dijadikan cermin (pedoman) perbaikan bagi aktivitas selanjutnya (Poerwanti, 2009:5.45). Dalam tahap ini peneliti dan kolaborator mendiskusikan hasil pengamatan selama pelaksanaan tindakan berlangsung. Kekurangan yang ditemui dalam siklus sebelumnya digunakan sebagai dasar 
penyusunan rencana pelaksaan tindakan pada siklus selanjutnya. Dengan demikian maka siklus selanjutnya akan berjalan lebih baik dari pada siklus sebelumnya

\section{Subyek Penelitian}

Subyek penelitian dalam penelitian ini adalahguru Kelas VI dan siswa berjumlah 20 siswa dengan jumlah siswa laki-laki 8 dan jumlah siswa perempuan 12 tahun ajaran 2015/2016

\section{Instrumen Penelitian}

Instrumen yang digunakan dalam penelitian ini terdiri dari
a. Observasi
b. Catatan Harian (Field Note)
c. Test
d. Dokumentasi

\section{Teknik Pengumpulan Data}

Teknik pengumpulan data yang dilakukan dalam penelitian ini meliputi teknik tes dan teknik non tes, sebagaiberikut:

1. Tes

Teknik tes adalah seperangkat tugas yang harus dikerjakan atau sejumlah pertanyaan yang harus dijawab oleh peserta didik untuk mengukur tingkat pemahaman dan penguasaannya terhadap cakupan materi yang dipersyaratkan dan sesuai dengan tujuan pengajaran tertentu (Poerwanti, 2008:1.5).

Dalam penelitian ini teknik tes berupa tes tertulis yaitu dengan menggunakan alat pengumpulan data berupa soal evaluasi yang diberikan kepada siswa pada setiap akhir pertemuan dalam setiap siklus. Tes dalam penelitian ini digunakan untuk mengukur atau memberi angka terhadap proses pembelajaran ataupun pekerjaan siswa sebagai hasil belajar yang merupakan cerminan tingkat penguasaan terhadap materi yang diajarkan.

2. Nontes
Teknik nontes adalah suatu alat penilaian yang digunakan untuk mendapatkan informasi tertentu tentang keadaan peserta tes tanpa menggunakan tes (Hamdani, 2011:316). Dalam penelitian ini, teknik nontes dilakukan dengan observasi, dokumentasi, catatan lapangan.

a. Observasi.

Teknikpengumpulan data lewat megnamati setiap kejadian berlangsung serta mencatatnya dengan alat observasi sesuai hal-hal diamati atau diteliti (Sanjaya, 2010:86). Observasi dalam penelitian ini digunakan untuk mengamati aktivitas siswa dan keterampilan guru dalam pembelajaran PKN dengan menggunakan pendekatan kooperatif tipe Contextual Teaching and Learning (CTL) selama pelaksanaan tindakan dalam penelitian berlangsung.

b. Teknik Dokumentasi

Dokumentasi berasal dari kata dokumen, yang artinya barang-barang tertulis. Dalam melaksanakan metode dokumentasi, peneliti menyelidiki bendabenda tertulis seperti buku-buku, majalah, dokumenen, peraturan-peraturan, notulen rapat, catatan harian, dan sebagainya (Novianti, 2012). Dalam penelitian ini metode dokumen digunakan untuk memperoleh data nama-nama siswa subyek penelitian dan nilai atau hasil evaluasi siswa yang digunakan untuk mengetahui besarnya peningkatan hasil belajar siswa.

\section{HASIL PENELITIAN DAN PEMBAHASAN}

Proses Peningkatan Pembelajaran Pkn Materi Persiapan Kemerdekaan Indonesia Melalui Pendekatan Contextual Teaching And Learning (CTL) Pada siswa kelas VI SD Negeri Muka Blang melalui beberapa tahapan dalam penelitian iniakan dijelaskan sebagai berikut

\section{Siklus I}

1.Hasil Belajar

Setelah dilakukan pelaksanaan tindakan pembelajaran siklus I diperoleh 
data hasil belajar siswa yang dapat dilihat pada tabel berikut ini:

Tabel 1 Data Hasil Belajar Siklus I

\begin{tabular}{|c|c|c|}
\hline \multirow{2}{*}{$\begin{array}{l}\text { Prestasi } \\
\text { Belajar }\end{array}$} & \multicolumn{2}{|c|}{$\begin{array}{c}\text { Hasil Tes Siklus I (Skor } \\
\text { Dasar) }\end{array}$} \\
\hline & $\begin{array}{c}\text { Banyak } \\
\text { Siswa }\end{array}$ & $\begin{array}{l}\text { Persentase } \\
(\%)\end{array}$ \\
\hline $\begin{array}{l}\text { Jumlah siswa } \\
\text { tuntas belajar } \\
\text { (skor } \geq 70 \text { ) }\end{array}$ & 10 & $53 \%$ \\
\hline $\begin{array}{l}\text { Jumlah siswa } \\
\text { tidak tuntas } \\
\text { belajar } \quad \text { (skor } \\
\leq 69 \text { ) }\end{array}$ & 9 & $47 \%$ \\
\hline $\begin{array}{l}\text { Rata-rata } \\
\text { kelas }\end{array}$ & \multicolumn{2}{|c|}{$\mathbf{7 0 , 5 3}$} \\
\hline
\end{tabular}

\section{Observasi Proses Pembelajaran}

Peneliti mengamati siswa pada waktu pembelajaran. Apakah dengan melakukan penerapan metode Contextual Teaching and Learning (CTL) dapat membantu siswa untuk memahami konsep Persiapan Kemerdekaan Indonesia dan penggunaannya. Berdasarkan observasi menunjukkan bahwa dengan metode Contextual Teaching and Learning (CTL) siswa lebih tertarik dan senang mengikuti kegiatan pembelajaran PKN, meskipun masih terlihat ada beberapa siswa yang kurang antusias. Guru membimbing siswa, mengadakan evaluasi dan mengolah data yang diperoleh, mengidentifikasi dan menginterpretasi data untuk menentukan tingkat pencapaian tindakan.

\section{Refleksi}

Berdasarkan analisis terhadap hasil tes belajar siswa pada siklus 1 , diperoleh data nilai rata-rata kelas yang dicapai adalah 70,53 yang berarti sudah memenuhi indikator keberhasilan yang ditentukan yaitu 70. Namun, persentase ketuntasan belajar klasikal belum memenuhi indikator ketuntasan belajar klasikal yaitu 53\%. Meskipun rata-rata kelas pada siklus I telah memenuhi KKM, ketuntasan belajar klasikal jauh dari kriteria keberhasilan $85 \%$. Hal ini disebabkan karena siswa hanya fokus terhadap materi yang ditugaskan pada saat pembelajaran di kelompok. Mereka kurang memperhatikanpenjelasanteman

kelompoknya pada saat kegiatan mempresentasikan hasil diskusi di kelompok asal, sehingga perolehan nilai individu belum mencapai KKM.

Ketidak tuntasan belajar klasikal juga berlaku pada nilai aktivitas belajar siswa. Persentase hasil observasi aktivitas belajar siswa selama proses pembelajaran pada siklus I dalam mengikuti pembelajaran model Contextual Teaching and Learning (CTL) sebesar 53\% Hal ini disebabkan karena siswa baru pertama kali belajar menggunakan model Contextual Teaching and Learning (CTL), jadi masih ada beberapa siswa yang masih belum paham mengikuti langkah-langkah pembelajaran model Contextual Teaching and Learning (CTL). Selain itu guru dalam menyampaikan materi pelajaran kurang memberi kesempatan kepada siswa untuk bertanya maupun menanggapi materi yang belum dipahami, sehingga siswa cenderung pasif pada saat pembelajaran.

Hambatan dari pihak guru yaitu guru masih mengalami kesulitan dalam penerapan model Contextual Teaching and Learning (CTL) karena belum terbiasa. Tahapan-tahapan yang ada pada model Contextual Teaching and Learning (CTL) dilakukan dengan cukup baik. Namun, kemampuan guru dalam mengelola kelas masih kurang baik. Suasana kelas gaduh pada saat proses pengelompokan. Hal ini disebabkan karena volume suara guru kurang keras sehingga tidak bisa menjangkau semua siswa. Selain itu, pembelajaran selesai melebihi waktu yang telah ditentukan. Hal ini dikarenakan, penggunaan waktu yang cukup lama dalam menjelaskan langkah-langkah pembelajaran model Contextual Teaching and Learning (CTL) dan proses pengelompokan. Berdasarkan hasil refleksi tersebut, perlu dilakukan perbaikan dengan tindakan siklus II.

\section{Revisi}


Berdasarkan hasil refleksi siklus I terhadap hambatan yang ada baik dari pihak siswa maupun guru tersebut, maka akan dilakukan revisi atau perbaikan pada siklus II dengan menerapkan model Contextual Teaching and Learning (CTL). Hal-hal yang akan dilakukan pada siklus II antara lain: (1) guru memberi arahan kepada siswa supaya tidak terlalu fokus pada materi yang ditugaskan saja, tetapi juga terhadap materi yang disampaikan teman sekelompoknya; (2) pada saat penjelasan materi, guru memberikan kesempatan kepada siswa untuk bertanya maupun menanggapi materi yang disampaikan; (3) guru memotivasi siswa supaya tidak malu atau takut untuk bertanya maupun berpendapat; (4) volume suara guru lebih diperkeras lagi supaya bisa menjangkau semua siswa; (5) guru mengelola waktu pembelajaran secara lebih efisien terhadap penggunaan waktu untuk proses pengelompokan.

3.Keterampilan Guru dalam Pembelajaran Siklus 1

Hasil observasi keterampilan guru selama pelaksanaan tindakan pada siklus 1 diperoleh data yang tersaji pada tabel 4.2 sebagai berikut

Tabel 2 Data Keterampilan Guru Siklus 1

\begin{tabular}{|l|l|c|}
\hline No & \multicolumn{1}{|c|}{ Indikator } & $\begin{array}{c}\text { Siklus } \\
\text { I }\end{array}$ \\
\hline 1 & $\begin{array}{l}\text { Mengondisikan kelas agar } \\
\text { siswa siap mengikuti } \\
\text { pembelajaran (keterampilan } \\
\text { membuka pelajaran) }\end{array}$ & 4 \\
\hline 2 & $\begin{array}{l}\text { Melakukan apersepsi } \\
\text { (keterampilan } \\
\text { membukapelajaran) }\end{array}$ & 4 \\
\hline 3 & $\begin{array}{l}\text { Menyampaikan tujuan } \\
\text { pembelajaran (keterampilan } \\
\text { membuka pelajaran }\end{array}$ & 2 \\
\hline 4 & $\begin{array}{l}\text { Membangun pengetahuan } \\
\text { siswa melalui media } \\
\text { pembelajaran (keterampilan } \\
\text { mengadakan variasi; CTL: } \\
\text { konstruktivis) }\end{array}$ & 4 \\
\hline 5 & $\begin{array}{l}\text { Mengajukan pertanyaan } \\
\text { keterampilan bertanya; }\end{array}$ & 4 \\
\hline
\end{tabular}

\begin{tabular}{|c|c|c|}
\hline & $C T L:$ bertanya) & \\
\hline 6 & $\begin{array}{lr}\text { Menjelaskan } & \text { materi } \\
\text { pelajaran } & \text { (keterampilan } \\
\text { menjelaskan) }\end{array}$ & 3 \\
\hline 7 & $\begin{array}{lr}\text { Membimbing } & \text { siswa } \\
\text { melakukan } & \text { kegiatan } \\
\text { pengamatan } & \text { (keterampilan } \\
\text { mengelola } & \text { kelas; } \\
\text { CTL:inkuiri) } & \\
\end{array}$ & 4 \\
\hline 8 & $\begin{array}{l}\text { Membimbing siswa belajar } \\
\text { dalam diskusi kelompok } \\
\text { (Keterampilan } \\
\text { membimbing diskusi } \\
\text { kelompok kecil; CTL: } \\
\text { masyarakat belajar) }\end{array}$ & 3 \\
\hline 9 & $\begin{array}{lrr}\text { Membimbing } & \text { siswa } \\
\text { mempresentasikan } & \text { hasil } \\
\text { diskusi } & \text { kelompok } \\
\text { (Keterampilan } & \text { mengajar } \\
\text { kelompok kecil } & \text { dan } \\
\text { perorangan; } & & C T L: \\
\text { pemodelan) } & & \end{array}$ & 2 \\
\hline 10 & $\begin{array}{lr}\text { Memberikan } & \text { penguatan } \\
\text { (keterampilan } & \text { memberi } \\
\text { penguatan) } & \\
\end{array}$ & 3 \\
\hline 11 & $\begin{array}{l}\text { Menyimpulkan hasil } \\
\text { pembelajaran (keterampilan } \\
\text { menutup pelajaran) }\end{array}$ & 3 \\
\hline 12 & $\begin{array}{lr}\text { Melakukan } & \text { refleksi } \\
\text { (keterampilan } & \text { menutup } \\
\text { pelajaran; } C T L \text { : refleksi) }\end{array}$ & 3 \\
\hline 13 & $\begin{array}{l}\text { Memberikan } \\
\text { (keterampilan } \\
\text { menutuppelajaran; } \\
\text { penilaian autentik) }\end{array}$ & 2 \\
\hline \multicolumn{2}{|c|}{ Jumlah } & 41 \\
\hline \multicolumn{2}{|c|}{ Rata-Rata } & 3,2 \\
\hline \multicolumn{2}{|c|}{ Kategori } & Baik \\
\hline
\end{tabular}

4. Aktivitas siswa dalam Pembelajaran Siklus 1

Hasil observasi aktivitas siswa diperoleh dari analisiss data hasil pengamatan guru terhadap aktivitas siswa selama mengikuti pembelajaran PKN melalui penerapan model Contextual Teaching and Learning (CTL) dengan multimedia. Dimana pengamatan tesebut dilakukan dengan instrumen berupa lembar 
pengamatan aktivitas siswa dan lembar catatan lapangan. Data hasil observasi mengenai aktivitas siswa pada siklus 1 dapat dilihat pada tabel 3

Tabel 3 Data Aktivitas Siswa Siklus

\begin{tabular}{|c|c|c|}
\hline No & Indikator & $\begin{array}{c}\text { Rata-Rata } \\
\text { Skor }\end{array}$ \\
\hline 1 & $\begin{array}{l}\text { Kesiapan } \\
\text { siswamengikuti } \\
\text { pembelajaran(emotional } \\
\text { activities) }\end{array}$ & 2,63 \\
\hline 2 & $\begin{array}{l}\text { Menanggapi apersepsi } \\
\text { (oral activities, mental } \\
\text { activities) }\end{array}$ & 2,42 \\
\hline 3 & $\begin{array}{l}\text { Menyimak } \\
\text { informasitujuan } \\
\text { pembelajaran(listening } \\
\text { activities) }\end{array}$ & 2,53 \\
\hline 4 & $\begin{array}{lr}\begin{array}{l}\text { Membangun } \\
\text { pengetahuan }\end{array} & \text { baru } \\
\text { melalui } & \text { media } \\
\text { pembelajaran } & \text { (visual } \\
\text { activities, } & \text { mental } \\
\begin{array}{l}\text { activities; } \\
\text { konstruktivis) }\end{array} & \text { CTL: } \\
\end{array}$ & 2,42 \\
\hline 5 & $\begin{array}{l}\text { Menanggapi pertanyaan } \\
\text { (oral activities; CTL: } \\
\text { bertanya) }\end{array}$ & 2,47 \\
\hline 6 & $\begin{array}{lr}\begin{array}{l}\text { Menyimak } \\
\text { guru }\end{array} & \begin{array}{r}\text { penjelasan } \\
\text { (listening }\end{array} \\
\text { activities) } & \\
\end{array}$ & 2,68 \\
\hline 7 & 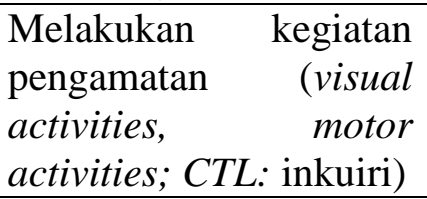 & 2,53 \\
\hline 8 & $\begin{array}{lr}\text { Melaksanakan } & \text { diskusi } \\
\text { secara kelompok (oral } \\
\text { activities, } \quad \text { writing } \\
\text { activitie, } \quad \text { listening } \\
\text { activities; } \quad \text { CTL: } \\
\text { masyarakat belajar) }\end{array}$ & 2,37 \\
\hline 9 & $\begin{array}{lr}\text { Mempresentasikan hasil } \\
\text { diskusi kelompok (oral } \\
\text { activities, } \\
\text { activities, } & \text { mental } \\
\text { activities; } & \text { CTL: } \\
\text { pemodelan) } & \\
\end{array}$ & 2,16 \\
\hline 10 & Menyimpulkan & 2,37 \\
\hline
\end{tabular}

\begin{tabular}{|c|l|c|}
\hline 11 & $\begin{array}{l}\text { pembelajaran (listening } \\
\text { activities, } \\
\text { activities) }\end{array}$ & oral \\
\hline 12 & $\begin{array}{l}\text { Menyimak } \\
\text { refleksipembelajaran } \\
\text { (oralactivities, mental } \\
\text { activities) }\end{array}$ & 2,37 \\
\hline $\begin{array}{l}\text { Mengerjakan evaluasi } \\
\text { writing activities, } \\
\text { emotional activities) }\end{array}$ & 2,47 \\
\hline & \begin{tabular}{l} 
Jumlah Rata-Rata Skor \\
\hline
\end{tabular} & 29,42 \\
\hline
\end{tabular}

Data hasil pelaksanaan tindakan siklus I seperti yang dipaparkan di atas, menunjukkan bahwa hasil pembelajaran dengan menerapkan model Contextual Teaching and Learning (CTL) masih kurang memuaskan. Untuk itu peneliti melaksanakan tindakan lanjutan, yaitu berupa pelaksanaan tindakan siklus II guna memperbaiki hasil pembelajaran pada siklus I

\section{SIKLUS II}

\section{Hasil Belajar}

Setelah dilakukan pelaksanaan tindakan pembelajaran siklus II diperoleh data hasil belajar siswa yang dapat dilihat pada tabel berikut ini:

Tabel 4 Data Haisl Belajar Siklus II

\begin{tabular}{|l|c|c|}
\hline \multirow{2}{*}{\begin{tabular}{l}
\multirow{2}{*}{$\begin{array}{l}\text { Prestasi } \\
\text { Belajar }\end{array}$} \\
\cline { 2 - 3 }
\end{tabular}} & $\begin{array}{c}\text { Hasil Tes Siklus II (Skor } \\
\text { Banyak } \\
\text { Siswa }\end{array}$ & Persentase (\%) \\
\hline $\begin{array}{l}\text { Jumlah } \\
\text { siswa tuntas } \\
\text { belajar } \\
\text { (skor } \geq 70)\end{array}$ & 18 & $95 \%$ \\
\hline $\begin{array}{l}\text { Jumlah } \\
\text { siswa tidak } \\
\text { tuntas } \\
\text { belajar } \\
\text { (skor } \leq 69)\end{array}$ & 1 & $5 \%$ \\
\hline $\begin{array}{l}\text { Rata-rata } \\
\text { kelas }\end{array}$ & \multicolumn{2}{|c|}{$\mathbf{7 9 , 7 4}$} \\
\hline
\end{tabular}

2. Observasi Proses Pembelajaran 
Peneliti mengamati siswa pada waktu pembelajaran. Apakah dengan melakukan penerapan metode Contextual Teaching and Learning (CTL) dapat membantu siswa untuk memahami konsep Persiapan Kemerdekaan Indonesia dan penggunaannya. Berdasarkan observasi setelah guru memodifikasi metode Contextual Teaching and Learning (CTL) dalam praktek PKN dengan penyampaian materi menggunakan media lingkungan menunjukkan bahwa siswa lebih tertarik, senang dan antusias mengikuti kegiatan pembelajaran PKN. Guru membimbing siswa, mengadakan evaluasi dan mengolah data yang diperoleh, mengidentifikasi dan menginterpretasi data untuk menentukan tingkat pencapaian tindakan.

\section{Refleksi}

Berdasarkan analisis data hasil belajar siswa pada siklus II, pembelajaran yang telah dilakukan dapat dikatakan berhasil karena nilai rata-rata kelas telah memenuhi KKM yaitu minimal 70 untuk mata pelajaran PKN materi Persiapan Kemerdekaan Indonesia dan penggunaannya. Hasil belajar pada pelaksanaan tindakan pembelajaran siklus I sebesar 70,53 mengalami peningkatan menjadi 79,74. Ketuntasan belajar klasikal pada siklus II juga menjadi indikator keberhasilan pelaksanaan tindakan pembelajaran yang mencapai $85 \%$. Dengan demikian seluruh aspek yang diteliti sudah memenuhi indikator keberhasilan, sehingga penelitian dianggap selesai.

3. Ketermpilan Guru dalam Pembelajaran Siklus II

Hasil observasi keterampilan guru selama pembelajaran PKNmelalui penerapan model Contextual Teaching and Learning (CTL) dengan multimedia pada siklus 2 pertemuan I diperoleh data yang dapat dilihat pada tabel dibawah ini

Tabel 4.Data Keterampilan Guru Siklus 2

\begin{tabular}{|c|c|c|}
\hline No & Indikator & $\begin{array}{c}\text { Siklus } \\
\text { II }\end{array}$ \\
\hline 1 & Mengondisikan kelas agar & 4 \\
\hline
\end{tabular}

\begin{tabular}{|c|c|c|}
\hline & $\begin{array}{ll}\text { siswa siap } & \text { mengikuti } \\
\text { pembelajaran } & \\
\text { (keterampilan } & \text { membuka } \\
\text { pelajaran) } & \\
& \end{array}$ & \\
\hline 2 & $\begin{array}{l}\text { Melakukan apersepsi } \\
\text { (keterampilan } \\
\text { membukapelajaran) }\end{array}$ & 4 \\
\hline 3 & $\begin{array}{l}\text { Menyampaikan } \text { tujuan } \\
\text { pembelajaran } \\
\text { (keterampilan membuka } \\
\text { pelajaran }\end{array}$ & 3 \\
\hline 4 & $\begin{array}{l}\text { Membangun pengetahuan } \\
\text { siswa melalui media } \\
\text { pembelajaran } \\
\text { (keterampilan mengadakan } \\
\text { variasi; } \\
\text { konstruktivis) } \\
\end{array}$ & 4 \\
\hline 5 & $\begin{array}{lr}\text { Mengajukan } & \text { pertanyaan } \\
\text { (keterampilan } & \text { bertanya; } \\
C T L: \text { bertanya) } & \\
\end{array}$ & 4 \\
\hline 6 & $\begin{array}{l}\text { Menjelaskan materi } \\
\text { pelajaran (keterampilan } \\
\text { menjelaskan) }\end{array}$ & 3 \\
\hline 7 & $\begin{array}{lr}\text { Membimbing } & \text { siswa } \\
\text { melakukan } & \text { kegiatan } \\
\text { pengamatan } & \text { (keterampilan } \\
\text { mengelola } & \text { kelas; } \\
C T L: \text { inkuiri) } & \\
\end{array}$ & 4 \\
\hline 8 & $\begin{array}{l}\text { Membimbing siswa belajar } \\
\text { dalam diskusi kelompok } \\
\text { (Keterampilan } \\
\text { membimbing diskusi } \\
\text { kelompok kecil; CTL: } \\
\text { masyarakat belajar) }\end{array}$ & 4 \\
\hline 9 & $\begin{array}{lrr}\text { Membimbing } & \text { siswa } \\
\text { mempresentasikan } & \text { hasil } \\
\text { diskusi } & \text { kelompok } \\
\text { (Keterampilan mengajar } \\
\text { kelompok kecil } & \text { dan } \\
\text { perorangan; } & & C T L \text { : } \\
\text { pemodelan) } & & \end{array}$ & 3 \\
\hline 10 & $\begin{array}{lr}\text { Memberikan } & \text { penguatan } \\
\text { (keterampilan } & \text { memberi } \\
\text { penguatan) } & \\
\end{array}$ & 4 \\
\hline 11 & $\begin{array}{l}\text { Menyimpulkan } \quad \text { hasil } \\
\text { pembelajaran } \\
\text { (keterampilan menutup } \\
\text { pelajaran) }\end{array}$ & 4 \\
\hline 12 & Melakukan & 3 \\
\hline
\end{tabular}




\begin{tabular}{|c|l|c|}
\hline & $\begin{array}{l}\text { (keterampilan menutup } \\
\text { pelajaran; CTL: refleksi) }\end{array}$ & \\
\hline 13 & $\begin{array}{l}\text { Memberikan evaluasi } \\
\text { (keterampilan } \\
\text { menutuppelajaran; CTL: } \\
\text { penilaian autentik) }\end{array}$ & 3 \\
\hline Jumlah & 47 \\
\hline Rata-Rata & 3,6 \\
\hline Kategori & $\begin{array}{c}\text { Sangat } \\
\text { Baik }\end{array}$ \\
\hline
\end{tabular}

4. Aktivitas Siswa dalam Pembelajaran Siklus 2

Hasil observasi aktivitas siswa diperoleh dari analisiss data hasil pengamatan guru terhadap aktivitas siswa selama mengikuti pembelajaran PKN melalui penerapan model Contextual Teaching and Learning (CTL). Dimana pengamatan tesebut dilakukan dengan instrumen berupa lembar pengamatan aktivitas siswa dan lembar catatan lapangan. Data hasil observasi mengenai aktivitas siswa pada siklus 2 dapat dilihat pada tabel 4.9 .

Tabel 5 Data Aktivitas Siswa Siklus 2

\begin{tabular}{|c|c|c|}
\hline No & Indikator & $\begin{array}{l}\text { Rata- } \\
\text { Rata } \\
\text { Skor }\end{array}$ \\
\hline 1 & $\begin{array}{l}\text { Kesiapan } \\
\text { siswamengikuti } \\
\text { pembelajaran(emotional } \\
\text { activities) }\end{array}$ & 3,16 \\
\hline 2 & $\begin{array}{l}\text { Menanggapi apersepsi } \\
\text { (oral activities, mental } \\
\text { activities) }\end{array}$ & 3,26 \\
\hline 3 & $\begin{array}{l}\text { Menyimak } \\
\text { informasitujuan } \\
\text { pembelajaran(listening } \\
\text { activities) }\end{array}$ & 3,21 \\
\hline 4 & $\begin{array}{lr}\begin{array}{l}\text { Membangun } \\
\text { pengetahuan }\end{array} & \text { baru } \\
\text { melalui } & \text { media } \\
\text { pembelajaran } & \text { (visual } \\
\text { activities, } & \text { mental } \\
\begin{array}{l}\text { activities; } \\
\text { konstruktivis) }\end{array} & \text { CTL: } \\
\end{array}$ & 3,11 \\
\hline 5 & Menanggapi pertanyaan & 3,32 \\
\hline
\end{tabular}

\begin{tabular}{|c|c|c|}
\hline & $\begin{array}{l}\text { (oral activities; CTL: } \\
\text { bertanya) }\end{array}$ & \\
\hline 6 & $\begin{array}{lr}\begin{array}{l}\text { Menyimak } \\
\text { guru }\end{array} & \text { penjelasan } \\
\text { activities) } & \\
\end{array}$ & 3,26 \\
\hline 7 & $\begin{array}{lr}\begin{array}{l}\text { Melakukan } \\
\text { pengamatan }\end{array} & \text { kegiatan } \\
\text { (visual } \\
\text { activities, } & \text { motor } \\
\text { activities; } \text { CTL: } \text { inkuiri) }\end{array}$ & 3,42 \\
\hline 8 & $\begin{array}{lr}\text { Melaksanakan } & \text { diskusi } \\
\text { secara kelompok (oral } \\
\text { activities, } \quad \text { writing } \\
\text { activitie, } \quad \text { listening } \\
\text { activities; } \quad \text { CTL: } \\
\text { masyarakat belajar) }\end{array}$ & 3,21 \\
\hline 9 & $\begin{array}{l}\text { Mempresentasikan hasil } \\
\text { diskusi kelompok (oral } \\
\text { activities, mental } \\
\text { activities, } \\
\text { activities; } \\
\text { pemodelan) }\end{array}$ & 3,26 \\
\hline 10 & $\begin{array}{l}\text { Menyimpulkan hasil } \\
\text { pembelajaran } \\
\text { activities, } \\
\text { activities) }\end{array}$ & 3,42 \\
\hline 11 & $\begin{array}{l}\text { Menyimak } \\
\text { refleksipembelajaran } \\
\text { (oralactivities, mental } \\
\text { activities) }\end{array}$ & 3,37 \\
\hline \multirow[t]{3}{*}{12} & $\begin{array}{l}\text { Mengerjakan evaluasi } \\
\text { (writing activities, } \\
\text { emotional activities) }\end{array}$ & 3,26 \\
\hline & Jumlah Rata-Rata Skor & 39,26 \\
\hline & Kategori & $\begin{array}{c}\text { Sangat } \\
\text { Baik }\end{array}$ \\
\hline
\end{tabular}

Hasil belajar siswa dalam pembelajaran PKN melalui pendekatan Contextual Teaching and Learning (CTL), mengalami peningkatan. Rata-rata nilai siswa meningkat dari siklus I sebesar 79,53 menjadi 79,74 pada siklus II. Persentase ketuntasan belajar individual siswa juga mengalami peningkatan dari $53 \%$ atau 10 dari 19 siswa pada siklus I menjadi 95\% atau 18 dari 19 siswa pada siklus II.

Berdasarkan data tersebut, pencapaian hasil belajar siswa pada siklus kedua sudah mencapai indikator keberhasilan yaitu $80 \%$ 
siswa mengalami ketuntasan belajar individual $\geq 70$. Peningkatan hasil belajar siswa dalam dalam pembelajaran PKN melalui Contextual Teaching and Learning (CTL) ini juga didukung oleh pendapat Hasil belajar merupakan hasil atau kecakapan yang telah dicapai siswa dalam kurun waktu tertentu setelah melakukan belajar. Hasil belajar dapat juga diartikan sebagai penguasaan pengetahuan, keterampilan yang dikembangkan oleh mata pelajaran ditunjukkan dengan nilai atau angka diberikan oleh guru.

Hasil belajar merupakan perubahan perilaku diperoleh siswa setelah mengalami kegiatan belajar. Perolehan aspek-aspek perubahan perilaku tergantung apa yang dipelajari oleh siswa. Menurut Bloom (dalam Rifa'i, 2009:85) terdapat tiga ranah yang merupakan hasil belajar yakni kognitif, afektif, dan psikomotor.

\section{KESIMPULAN}

Berdasarkan hasil observasi penelitian pembelajaran PKN melalui pendekatan Contextual Teaching and Learning (CTL) pada siswa Kelas VI SD Negeri Muka Blang dan pembahasan yang disajikan pada bab IV dapat ditarik simpulan Pembelajaran PKN melalui pendekatan Contextual Teaching and Learning (CTL) pada siswa Kelas VI SD Negeri Muka Blang dapat meningkatkan hasil belajar PKN siswa. Ditunjukkan dengan data hasil belajar siswa pada siklus I persentase mendapat $53 \%$ menjadi $95 \%$ pada siklus II. Hasil belajar PKN siswa sudah memenuhi indikator keberhasilan yaitu sekurang-kurangnya ketuntasan klasikal mencapai $80 \%$ dengan KKM PKN Kelas VI SD Negeri Muka Blang tahun ajaran 2015/2016 adalah 70 .

\section{DAFTAR PUSTAKA}

Arikunto, Suharsimi, dkk. 2009. Penelitian Tindakan Kelas. Jakarta: Bumi Aksara.
Budimansyah, 2010:118. Model-Model PembelajaranMengembangkanPr ofesionalisme Guru. Jakarta: Raja Grafindo Persada

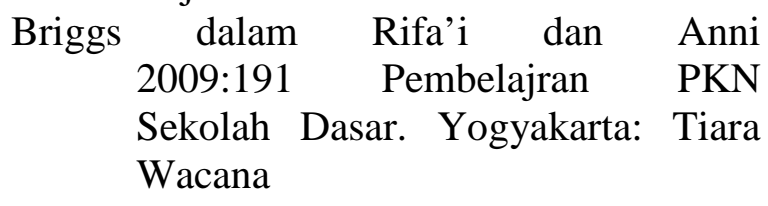

Depdiknas:2006 Undang-undang Republik Indonesia Nomor 20 Tahun 2003. Bandung: Citra Umbara.

Ian 2010. Cooperative Learning Teori \& Aplikasi PAIKEM. Yogyakarta: Pustaka Pelajar.

Nurhadi 2003:11 Psikologi Pendidikan. Semarang: UNNES PRESS.

Rusman,011:80 Model-Model Pembelajaran Mengembangkan Profesionalisme Guru.Jakarta: Raja Grafindo Persada.

Rifa'i, 2009:237 Pembelajaran Kontekstual (Contextual Teaching and Learning/CTL) dan Penerapanya Dalam KBK. Malang: Universitas Negeri Malang.

Sanjaya, 2012:33.

MenganalRevisiTaksonomiBloom. http://yunikatminingsih.blogspot.co $\mathrm{m} / 2012 / 10 / 2$-mengenalevisitaksonomi- bloom-oleh.html. [diunduh tanggal Desember 2015] 